\title{
KETERHUBUNGAN SUPERVISI KEPALA SEKOLAH DAN MANAJEMEN PEMBELAJARAN TERHADAP PRESTASI BELAJAR SISWA
}

\author{
Sri Lindusari Sidik \\ SMP Negeri SATAP 2 Krangkeng, Purwajaya, Krangkeng, Kabupaten Indramayu, Jawa Barat 45284, \\ srilindusarisidik@gmail.com
}

Citation: Sidik, S.L. (2020). Keterhubungan Supervisi Kepala Sekolah dan Manajemen Pembelajaran Terhadap Prestasi Belajar Siswa. Edum Journal, 3(2), 108-119

\begin{abstract}
ABSTRAK
Prestasi belajar siswa memerlukan keterpaduan dalam pengelolaan institusi pendidikan termasuk pengelolaan pembelajaran. Keterpaduan tersebut dapat dilihat dari seberapa besar korelasinya. Oleh karena itu, fokus dalam penelitian ini adalah apakah supervisi kepala sekolah dan manajemen pembelajaran berhubungan terhadap prestasi belajar siswa Metode penelitian yang digunakan adalah metode deskriptif dan verifikatif, dengan teknik pengumpulan data menggunakan angket skala Likert, terhadap 54 orang guru. Pengolahan hasil penelitian menggunakan teknik analisis regresi. Uji signifikansi menggunakan uji-F. Hasil penelitian menunjukkan bahwa: (1) Terdapat korelasi positif dan signifikan supervisi kepala sekolah dengan prestasi belajar siswa. (2) Terdapat korelasi positif dan signifikan manajemen pembelajaran dengan prestasi belajar siswa. (3) Terdapat korelasi positif dan signifikan supervisi kepala sekolah dan manajemen pembelajaran secara simultan dengan prestasi belajar siswa. Bertolak dari kondisi tersebut, penulis menyarankan, bahwa: (1) Hasil penelitian ini membuktikan adanya korelasi signifikan serta kontribusi antara supervisi kepala sekolah dan manajemen pembelajaran baik secara parsial maupun ganda dengan prestasi belajar siswa, oleh karena itu, maka Dinas Pendidikan perlu memberikan pelatihan kepada kepala sekolah agar pelaksanaan supervisi berlangsung lebih bagus lagi sehingga dapat mendorong peningkatan prestasi belajar siswa. Terutama pelatihan yang berkaitan dengan perencanaan dan pengendalian (pengawasan). (2) Kepala sekolah hendaknya menguatkan kembali kemampuan dan pemahamannya sebagai seorang pimpinan pada satuan pendidikan, yang berkaitan dengan supervisi. Dalam rangka meningkatkan prestasi belajar, maka kepala sekolah perlu melibatkan para guru dalam mengambil keputusan sehingga mereka akan merasa lebih terlibat dan bertanggungjawab atas pekerjaannya, serta berusaha lebih mengoptimalkan kemampuannya dalam upaya mencapai tujuan sekolah. (3) Menurut hasil penelitian terhadap variabel manajemen pembelajaran, diketahui bahwa variabel tersebut berada pada kategori bagus.
\end{abstract}

Kata Kunci: Manajemen Kelas, Manajemen Pembelajaran, Efektivitas Proses Pembelajaran

\begin{abstract}
Student learning achievement requires integration in the management of educational institutions including learning management. This integration can be seen from how big the correlation is. Therefore, the focus of this study is whether the supervision of the principal and learning management is related to student achievement. The research method used is descriptive and verification methods, with data collection techniques using a Likert scale questionnaire, on 54 teachers. Processing of research results using regression analysis techniques. The significance test used the F-test. The results showed that: (1) There is a positive and significant correlation between principal supervision and student achievement. (2) There is a positive and significant correlation between learning management and student achievement. (3) There is a positive and significant correlation between principal supervision and learning management simultaneously with student achievement. Starting from these conditions, the authors suggest that: (1) The results of this study prove that there are a significant correlation and contribution between principal supervision and learning management, both partially and double, with student achievement, therefore, the Education Office needs to provide training principals so that the implementation of supervision takes place even better to encourage increased student achievement. Especially training related to planning and control
\end{abstract}


(supervision). (2) The principal should re-strengthen his abilities and understanding as a leader in an educational unit, which is related to supervision. To improve learning achievement, the principal needs to involve teachers in making decisions so that they will feel more involved and responsible for their work and try to further optimize their abilities to achieve school goals. (3) According to the results of research on learning management variables, it is known that these variables are in a good category.

Keywords: Classroom Management, Learning Management, Learning Process Effectiveness

\section{PENDAHULUAN}

Sekolah merupakan salah satu sub sistem pendidikan yang berfungsi untuk membantu meningkatkan sumber daya manusia (Djuwarijah, 2008). Dari pendidikan yang diterima anak bangsa di bangku sekolah, akan mampu mengubah pola pikir dan daya kreativitas untuk membangun negara dan tingkat kesejahteraan yang lebih baik serta perekonomian yang meningkat (Hulukati \& Hulukati, 2015). Oleh karenanya, operasional pendidikan harus tertata dengan baik serta menghasilkan output yang berkualitas. Output atau lulusan satuan pendidikan yang bermutu hanya dapat dicapai oleh satuan pendidikan yang manajemen pembelajarannya benar (Tien, 2015).

Sebagai pilar menghasilkan lulusan yang bermnutu dimulai dari prestasi belajar siswa yang optimal. Prestasi belajar siswa yang tinggi cenderung merubah perilaku secara maksimal. Berkaitan dengan prestasi belajar, secara umum terbagi dua jenis yaitu prestasi akademik dan prestasi non akademik. Prestasi belajar siswa merupakan bagian dari prestasi akademik (Retnowati, Fatchan \& Astina, 2016). Keduanya penting, dengan tidak mengecilkan makna prestasi non akademik, untuk tataran sekolah menengah pertama (SMP) prestasi akademik harus lebih dipriorutaskan karena sekolah menengah pertama merupakan tingkatan akhir sebelum siswa memasuki sekolah menengah. Maknanya, lulusan SMP sebaiknya memiliki prestasi belajar yang tinggi karena dipersiapkan untuk melanjutkan ke jenjang yang lebih tinggi yaitu sekolah menengah.

Proses pendidikan memerlukan pembinaan secara terkoordinasi dan terarah dengan diharapkan siswa dapat mencapai prestasi belajar yang maksimal (Jamaluddin, 2019). Proses belajar mengajar merupakan inti dari proses pendidikan secara keseluruhan dengan guru dan siswa pemegang peranan penting (Musa, 2016; Kirom, 2017). "Proses belajar-mengajar merupakan suatu proses yang mengandung serangkaian kegiatan guru dan siswa atas dasar hubungan timbal balik yang 
berlangsung dalam situasi edukatif untuk mencapai tujuan tertentu" (Usman, 2008).

Prestasi akademik pada sekolah, misalnya prestasi capaian rata-rata tertinggi nilai ujian nasional (UN), meraih medali dalam olimpiade sains nasional (OSN), ataupun diterimanya lulusan di sekolah ternama. Prestasi belajar siswa dapat dilihat dari aspek kognitif, afektif dan psikomotor. Artinya, siswa yang prestasi belajarnya tinggi dapat dilihat dari ketiga aspek tersebut.

Kondisi ketiga aspek di atas, realitas pada tataran empirik masih belum menggembirakan. Masih ditemui berbagai permasalahan dalam operasionalnya. Berdasarkan pengalaman penulis yang sudah bekerja menjadi guru lebih dari sepuluh tahun menunjukkan bahwa para siswa sangat sulit mencapai kriteria ketuntasan minimal (KKM). Nilai ujian nasional cenderung menurun dalam tiga tahun terakhir. Perilaku dan sikap siswa masih memprihatinkan.

Prestasi belajar siswa yang tinggi dapat tercapai melalui manajemen pembelajaran yang benar. Manajemen pembelajaran dapat terimplementasi dengan baik jika fungsi pengawasannya berlangsung baik Salah satu pengawasan di sekolah yang paling baik manakala supervisi berlangsung sebagaimana mestinya. Supervisi pendidikan adalah hal yang sangat penting dilakukan untuk meningkatkan prestasi belajar. Oleh karena itu, dalam suatu lembaga pendidikan perlu adanya pelaksanaan supervisi. "Supervision also can be interpreted as a two ways interactional process that requires both the student and the supervisor to consciously engage each other within the spirit of professionalism, respect, collegiality and open-mindedness" (Abiddin, 2011:207) yang berarti pengawasan juga dapat diartikan sebagai dua cara proses interaksi yang memerlukan siswa dan supervisor untuk secara sadar terlibat satu sama lain dalam semangat profesionalisme, rasa hormat, kebersamaan dan pikiran yang terbuka.

Kepala sekolah mempunyai tugas dalam pengembangan dan peningkatan mutu pendidikan ditingkat sekolah. Dalam hal ini bertanggung jawab terhadap kelancaran pelaksanaan pendidikan dan proses kegiatan belajar mengajar di sekolah. Sebagai pengembang pendidikan dan pengajaran di sekolah merupakan tugas yang tidak ringan sebagaimana diamanatkan pada Permendiknas No. 13 Tahun 2007 tentang Standar Kepala Sekolah, bahwa sebagai kepala sekolah mempunyai kewajiban melaksanakan peraturan yang salah satunya adalah kompetensi supervisi. "Dalam rangka mengembangkan peningkatan pembelajaran secara bersama- 
sama semua personal agar bergerak ke arah pencapaian tujuan sesuai pelaksanaan tugas masing-masing secara efisien dan efektif" (Hamrin, 2011:51). Realita menunjukkan bahwa kepala sekolah merupakan pelopor keberhasilan sekolah dalam mendidik siswanya. Kepala sekolah dituntut professional dalam melaksanakan pekerjaannya. Sebagaimana disampaikan. Mulyasa (2007:42), bahwa pelaksanaan manajemen pada sekolah menuntut kepemimpinan kepala sekolah profesional yang memiliki kemampuan manajerial dan integritas pribadi untuk mewujudkan visi menjadi aksi, serta demokratis dan transparan dalam berbagai pengambilan keputusan. Bertolak dari paparan di atas, pertanyaan penelitian ini adalah bagaimana korelasi supervisi kepala sekolah dan manajemen pembelajaran dengan prestasi belajar siswa

\section{METODE PENELITIAN}

Penelitian ini dilaksanakan pada SMP Negeri di Kecamatan Jatibarang Kabupaten Indramayu. Metode penelitian yang digunakan adalah metode deskriptif dan verifikatif, dengan teknik pengumpulan data menggunakan angket skala Likert, terhadap 54 orang guru. Jumlah responden tersebut merupakan sampel hasil perhitungan menggunakan rumus Slovin. Populasi dalam penelitian ini adalah seluruh guru SMP Negeri di Kecamatan Jatibarang Kabupaten Indramayu. Proses pengambilan sampel dilakukan secara cluster proportional random sampling. Pengolahan hasil penelitian menggunakan teknik analisis regresi. Uji signifikansi menggunakan uji-F.

\section{HASIL PENELITIAN DAN}

\section{PEMBAHASAN}

\section{Hasil Penelitian}

Pada penelitian ini terdapat tiga variabel, yaitu variabel supervisi kepala sekolah, variabel manajemen pembelajaran dan variabel prestasi belajar siswa. Untuk mengetahui kecenderungan masing-masing variabel dapat dilihat pada tabel berikut. Berikut dapat dilihat kecenderungan supervisi kepala sekolah dilihat dari tiap dimensi, yaitu dimensi: perencanaan, pengorganisasian, pendayagunaan SDM, pembinaan, dan pengendalian.

Tabel 1. Kecenderungan Supervisi Kepala Sekolah

\begin{tabular}{llll}
\hline Dimensi & Persentase & Skor Capaian & Skor Maksimal \\
\hline Perencanaan & $65,20 \%$ & 3,26 & 5 \\
Pengorganisasian & $67,00 \%$ & 3,35 & 5 \\
Pendayagunaan SDM & $65,20 \%$ & 3,26 & 5 \\
Pembinaan & $64,20 \%$ & 3,21 & 5 \\
Pengendalian & $59,80 \%$ & 2,99 & 5 \\
\hline
\end{tabular}


Dari tabel di atas terlihat bahwa dimensi pengorganisasian merupakan skor tertinggi (67\%)sementara pengendalian skor terendah $(59,80 \%)$. Semua dimensi variabel supervisi kepala sekolah memerlukan peningkatan, terutama dimensi pengendalian. Berikut dapat dilihat kecenderungan manajemen pembelajaran dilihat dari tiap dimensi, yaitu dimensi: perencanaan proses pembelajaran, pelaksanaan proses pembelajaran, penilaian hasil pembelajaran, dan pengawasan proses pembelajaran.

Tabel 2. Kecenderungan Manajemen Pembelajaran

\begin{tabular}{llll}
\hline Dimensi & Persentase & Skor Capaian & Skor Maksimal \\
\hline Perencanaan Pembelajaran & $59,20 \%$ & 2,96 & 5 \\
Pelaksanaan Pembelajaran & $61,20 \%$ & 3,06 & 5 \\
Penilaian Hasil Pembelajaran & $60,00 \%$ & 3,00 & 5 \\
Pengawasan Pembelajaran & $59,60 \%$ & 2,98 & 5 \\
\hline
\end{tabular}

Dari tabel di atas terlihat bahwa dimensi pelaksanaan proses pembelajaran merupakan skor tertinggi $(61,20 \%)$. Perencanaan proses pembelajaran dan pengawasan proses pembelajaran samasama merupakan skor terendah dengan tingkat capaian kurang dari $60 \%$. Semua dimensi variabel manajemen pembelajaran perlu peningkatan, terutama dimensi perencanaan biaya dan dimensi perencanaan proses pembelajaran dan pengawasan proses pembelajaran. Kondisi tersebut dapat dilihat lebih jelas pada diagram berikut. Berikut dapat dilihat kecenderungan prestasi belajar siswa dilihat dari tiap dimensi, yaitu dimensi: aspek kognitif, aspek afektif, dan aspek psikomotor.

Tabel 3. Kecenderungan Prestasi Belajar Siswa

\begin{tabular}{llll}
\hline Dimensi & Persentase & Skor Capaian & Skor Maksimal \\
\hline Aspek Kognitif & $62,20 \%$ & 3,11 & 5 \\
Aspek Afektif & $60,00 \%$ & 3 & 5 \\
Aspek Psikomotor & $60,80 \%$ & 3,04 & 5 \\
\hline
\end{tabular}

Pada tabel di atas terlihat bahwa dimensi aspek kognitif merupakan skor tertinggi $(62,20 \%)$. Dimensi aspek afektif merupakan capaian skor terendah. Berikut ditampilkan hasil perhitungan statistik, untuk menjawab bagaimana korelasi variabel bebas terhadap variabel terikat. Berdasarkan hasil analisis uji korelasi dengan menggunakan IBM SPSS Statistics 22 diperoleh koefisien korelasi seperti yang ditampilkan pada tabel berikut. 
Tabel 4. Korelasi Var. Supervisi Kepala Sekolah

\begin{tabular}{llll}
\hline & & Supervisi_Kasek & Prestasi_Belajar_Siswa_Y \\
\hline Supervisi_Kasek & $\begin{array}{l}\text { Pearson } \\
\text { Correlation }\end{array}$ & 1 & $.286^{*}$ \\
& Sig. (2-tailed) & & .036 \\
& N & 54 & 54 \\
Prestasi_Belajar__ & Pearson & $.286^{*}$ & 1 \\
Siswa_Y & Correlation & .036 & \\
& Sig. (2-tailed) & .036 & \\
N & 54 & 54 \\
*. Correlation is significant at the 0.05 level (2-tailed). &
\end{tabular}

Dari tabel di atas diketahui bahwa koefisien korelasi antara variabel supervisi kepala sekolah dengan variabel prestasi belajar siswa adalah 0,286 dengan nilai sig sebesar 0,036. Hal ini menunjukkan adanya hubungan yang sedang dan signifikan antara variabel supervisi kepala sekolah dengan variabel prestasi belajar siswa. Sedangkan besaran sumbangan yang diberikan variabel supervisi kepala sekolah, dapat dilihat pada tebel berikut.

Tabel 5. Kontribusi Supervisi Kepala Sekolah terhadap Prestasi Belajar

\begin{tabular}{lllll}
\hline Model & $\mathrm{R}$ & $\mathrm{R}$ Square & Adjusted R Square & Std. Error of the Estimate \\
\hline 1 & $.286^{\mathrm{a}}$ & .082 & .064 & 9.813 \\
a. Predictors: (Constant), Supervisi_Kasek_X1 & \\
\hline
\end{tabular}

Pada tabel di atas terlihat bahwa 91,8 \% ditentukan oleh faktor lain. koefisien determinasi sebesar 0,082, maka Berdasarkan hasil analisis uji korelasi $\mathrm{KD}=\mathrm{R}^{2} \mathrm{X} 100 \%$ atau $\mathrm{KD}=0,082 \times 100 \%$ dengan menggunakan IBM SPSS Statistics $=8,2 \%$. Maknanya prestasi belajar siswa 22 diperoleh koefisien korelasi seperti yang mendapat kontribusi $8,2 \%$ dari variabel ditampilkan pada tabel berikut. supervisi kepala sekolah sedangkan sisanya

Tabel 6. Korelasi Variabel Manajemen Pembelajaran dengan Prestasi Belajar

\begin{tabular}{llll}
\hline & & Manajemen_Pembelajaran & Prestasi_Belajar_Siswa \\
\hline Manajemen_ & Pearson Correlation & 1 & $.276^{*}$ \\
Pembelajaran & Sig. (2-tailed) & & .043 \\
& $\mathrm{~N}$ & 54 & 54 \\
Prestasi_Belajar & Pearson Correlation & $.276^{*}$ & 1 \\
_Siswa & Sig. (2-tailed) & .043 & 54 \\
& $\mathrm{~N}$ & 54 & \\
*. Correlation is & Significant at the 0.05 level (2-tailed).
\end{tabular}

Dari tabel di atas diketahui bahwa koefisien korelasi antara variabel 
manajemen pembelajaran dengan variabel

belajar

siswa.

Sedangkan

besaran prestasi belajar siswa adalah 0,276 dengan sumbangan yang diberikan variabel nilai sig sebesar 0,043. Hal ini menunjukkan supervisi kepala sekolah, dapat dilihat pada adanya hubungan yang sedang dan tebel berikut.

signifikan antara variabel manajemen

pembelajaran dengan variabel prestasi

Tabel 7. Kontribusi Manajemen Pembelajaran terhadap Prestasi Belajar

\begin{tabular}{ccccc}
\hline Model & R & R Square & Adjusted R Square & Std. Error of the Estimate \\
\hline 1 & $.276^{\mathrm{a}}$ & .076 & .058 & 9.845 \\
\hline
\end{tabular}

Pada tabel di atas terlihat bahwa koefisien determinasi sebesar 0,076, maka $\mathrm{KD}=\mathrm{R}^{2} \mathrm{X} 100 \%$ atau $\mathrm{KD}=0,076 \times 100 \%$ $=7,6 \%$. Maknanya prestasi belajar siswa mendapat kontribusi $7,6 \%$ dari variabel manajemen pembelajaran sedangkan sisanya 92,4\% ditentukan oleh faktor lain.

\section{Pembahasan}

Permasalahan yang ingin dijawab dalam penelitian ini adalah adakah korelasi supervisi kepala sekolah dengan prestasi belajar siswa. Secara empirik, hasil penelitian ini menginformasikan bahwa terdapat korelasi yang positif dan signifikan antara supervisi kepala sekolah dengan prestasi belajar siswa Lebih dari itu ternyata supervisi berkontribusi atau berpengaruh terhadap prestasi belajar siswa. Besaran korelasi supervisi kepala sekolah dengan prestasi belajar siswa ditunjukkan oleh hasil penelitian bahwa supervisi kepala sekolah yang terdiri dari dimensi: (1) Perencanaan; (2) Pengorganisasian; (3) Pendayagunaan SDM; (4) Pembinaan; dan (5) Pengendalian
(Agus Dharma, 2003), membawa implikasi yang signifikan terhadap prestasi belajar siswa yang meliputi dimensi: (1) Aspek kognitif; (2) Aspek afektif; dan (3) Aspek psikomotor (Nasution, 2001). Namun demikian, prestasi belajar siswa ini tidak hanya berkorelasi dengan supervisi kepala sekolah saja, ada faktor lain (epsilon), selain dari manajemen pembelajaran, yang juga berkorelasi, yang tidak dikaji dalam penelitian ini.

Berdasarkan temuan empirik yang menunjukkan adanya korelasi yang positif dan signifikan supervisi kepala sekolah dengan prestasi belajar siswa, maka hasil penelitian ini memberikan beberapa informasi, diantaranya: (1) supervisi kepala sekolah memiliki korelasi yang berarti dengan prestasi belajar siswa. Salah satu cara untuk meningkatkan prestasi belajar siswa dapat dilakukan dengan meningkatkan supervisi kepala sekolah. (2) Korelasi supervisi kepala sekolah dengan prestasi belajar siswa adalah sebesar 0,286, 
sementara sisanya berkorelasi dengan variabel lain, selain variabel manajemen pembelajaran, yang tidak dikaji dalam penelitian ini (epsilon).

Hasil pengujian di atas sesuai dengan pendapat lain yang meneliti masalah supervisi kepala sekolah sekalipun hanya parsial, yaitu supervisi akademik kepala sekolah yang disampaikan Prasojo (2011) supervisi akademik dilakukan untuk mendorong seseorang lebih terlibat dalam pembuatan keputusan dan berimplikasi terhadap peningkatan kemampuan dan rasa memiliki, meningkatkan rasa tanggung jawab sehingga kinerjanya meningkat. Sebagai pemimpin sekolah, kepala sekolah memiliki peran yang cukup strategis untuk mengkoordinasikan dan menggerakkan semua sumber daya pendidikan yang tersedia. Oleh karena itu, kepala sekolah harus bertindak sebagai manajer dan pemimpin yang efektif dalam mewujudkan visi, misi, dan sasaran sekolahnya. Dengan kata lain, sebagai manajer ia harus mampu mengatur agar semua potensi sekolah dapat berfungsi secara optimal. Sehingga dengan supervisi akademik yang tepat, kepala sekolah akan dapat meningkatkan kemampuanya secara fungsional dalam mempengaruhi, mengarahkan, menggerakkan, dan mengembangkan para guru agar bekerja dengan maksimal sehingga tujuan pendidikan di sekolah dapat dicapai secara efektif dan efisien.

Selanjutnya, permasalahan yang ingin dijawab dalam penelitian ini adalah adakah korelasi manajemen pembelajaran dengan prestasi belajar siswa. Secara empirik, hasil penelitian ini menginformasikan bahwa terdapat korelasi yang positif dan signifikan antara manajemen pembelajaran dengan prestasi belajar siswa. Selain berkorelasi, manajemen pembelajaran juga mempengaruhi prestasi belajar siswa. Hal ini sangat logis karena manakala manajemen pembelajarannya bagus sangat mungkin prestasi belajar siswanya juga bagus karena salah satu faktor keberhasilan proses belajar mengajar adalah manajemen pembelajaran. Besaran korelasi manajemen pembelajaran dengan prestasi belajar siswa ditunjukkan oleh hasil penelitian bahwa manajemen pembelajaran yang terdiri dari dimensi: (1)

Perencanaan proses pembelajaran; (2)

Pelaksanaan proses pembelajaran; (3)

Penilaian hasil pembelajaran; dan (4) Pengawasan proses pembelajaran (Permendiknas No. 41 Thn 2007), membawa implikasi yang positif dan signifikan terhadap prestasi belajar siswa dengan dimensi: (1) Aspek kognitif; (2) Aspek afektif; dan (3) Aspek psikomotor (Nasution, 2001). Namun demikian prestasi belajar siswa ini tidak hanya berkorelasi dengan manajemen pembelajaran saja, ada 
faktor lain (epsilon), selain dari supervisi kepala sekolah, yang juga berkorelasi, yang tidak dikaji dalam penelitian ini.

Berdasarkan temuan empirik yang menunjukkan adanya korelasi yang signifikan manajemen pembelajaran dengan prestasi belajar siswa, maka hasil penelitian ini memberikan beberapa informasi, di antaranya: (1) manajemen pembelajaran memiliki korelasi yang berarti dengan prestasi belajar siswa. Oleh karenanya, salah satu cara untuk meningkatkan prestasi belajar siswa dapat dilakukan dengan meningkatkan manajemen pembelajaran, serta (2) Korelasi manajemen pembelajaran dengan prestasi belajar siswa adalah sebesar 0,276 , sementara sisanya berkorelasi dengan variabel lain, selain variabel supervisi kepala sekolah, yang tidak dikaji dalam penelitian ini (epsilon).

Hasil pengujian di atas sesuai dengan pendapat Gagne dan Brigge yang dikutip Mulyono (2012:7) bahwa pembelajaran sebagai rangkaian kejadian, peristiwa, kondisi yang sengaja dirancang untuk mempengaruhi peserta didik, sehingga proses belajaranya dapat berlangsung dengan mudah'. Sehingga proses mempengaruhi peserta ddik tersebut menggunakan fungsi manajemen yang benar dapat mendukung peningkatan prestasi belajar siswa.

\section{SIMPULAN DAN SARAN}

Berdasarkan hasil penelitian dan pembahasan, dapat dikemukakan beberapa kesimpulan sebagai berikut: (1) Terdapat korelasi positif dan signifikan supervisi kepala sekolah dengan prestasi belajar siswa. Besarnya koefisien korelasi 0,286 dengan koefisien diterminasi sebesar 8,2\%. (2) Terdapat korelasi positif dan signifikan manajemen pembelajaran dengan prestasi belajar siswa pada. Besarnya koefisien korelasi 0,276 dengan koefisien diterminasi sebesar 7,6\%.

Dari kesimpulan di atas, ada beberapa saran yang penulis ingin sampaikan yaitu: (1) Dengan hasil penelitian ini yang membuktikan adanya korelasi signifikan serta kontribusi antara supervisi kepala sekolah dan manajemen pembelajaran baik secara parsial maupun ganda dengan prestasi belajar siswa, maka Dinas Pendidikan perlu memberikan pelatihan kepada kepala sekolah agar pelaksanaan supervisi berlangsung lebih bagus lagi sehingga dapat mendorong peningkatan prestasi belajar siswa. Terutama pelatihan yang berkaitan dengan perencanaan dan pengendalian (pengawasan). (2) Kepala sekolah hendaknya menguatkan kembali kemampuan dan pemahamannya sebagai seorang pimpinan pada satuan pendidikan, yang berkaitan dengan supervisi. Dalam 
rangka meningkatkan prestasi belajar siswa,

maka kepala sekolah perlu melibatkan para guru dalam mengambil keputusan sehingga mereka akan merasa lebih terlibat dan bertanggungjawab atas pekerjaannya, serta berusaha lebih mengoptimalkan kemampuannya dalam upaya mencapai tujuan sekolah. (3) Menurut hasil penelitian terhadap variabel manajemen pembelajaran, diketahui bahwa variabel tersebut berada pada kategori bagus. Namun demikian, masih harus dikembangkan lagi terutama pada dimensi perencanaan dan proses pembelajaran karena tinggi rendahnya kemampuan guru dalam mengimplementasikan manajemen pembelajaran dapat mempengaruhi.

\section{DAFTAR PUSTAKA}

Abiddin, Norhasni Zainal, dkk. 2011. Effective Supervisory Approach in Enhancing Postgraduate Research Studies. International Journal of Humanities and Social Science.Vol 1 No. 2, Februari 2011. https://scholar.google.co.id (diakses Sabtu 15 Desember 2018 pukul 07:43 WIB).

Djuwarijah, D. (2008). Peningkatan Kualitas Sumber Daya Manusia Melalui Pendidikan Islam. $E l$ Tarbawi, 1(1), 13-26.

Hamrin. 2011. Sukses Menjadi Pengawas Sekolah: Tips dan Strategi Jitu Melaksanakan Tugas. Yogyakarta: Samudra Biru.

Hulukati, W., \& Hulukati, W. (2015). Peran lingkungan keluarga terhadap perkembangan anak. Jurnal Musawa IAIN Palu, 7(2), 265-282.

Jamaluddin. (2019). Upaya Peningkatan Kompetensi Guru dalam Pendampingan Kegiatan Ekstra Kurikuler di SD Teladan Metro, Tapis : Jurnal Penelitian Ilmiah, 3(2), 136158

Kirom, A. (2017). Peran guru dan peserta didik dalam proses pembelajaran berbasis multikultural. $A l$ Murabbi, 3(1), 69-80.

Mulyono. 2012. Manajemen Administrasi dan Organisasi Pendidikan. Yogyakarta: Ar-Ruzz Media

Musa, M. I. (2016). Pengembangan kompetensi guru terhadap pelaksanaan tugas dalam mewujudkan tenaga guru yang profesional. Jurnal Pesona Dasar, 2(4).

Nasution, S. 2001. Metode Penelitian Naturalistik Kualitatif. Bandung: Tarsito.

Permendiknas No 41 Tahun 2007 tentang Standar Proses.

Permendiknas No. 13 Tahun 2007 tentang Standar Kepala Sekolah.

Prasojo, Lantip Diat dan Sudiyono. (2011). Supervisi Pendidikan. Yogyakarta: Gama Media.

Retnowati, D. R., Fatchan, A., \& Astina, I. K. (2016). Prestasi akademik dan motivasi berprestasi mahasiswa S1 pendidikan geografi universitas negeri malang. Jurnal Pendidikan: Teori, Penelitian, dan Pengembangan, 1(3), 521-525. 
Tien, Y. C. (2015). Manajemen Peningkatan

Mutu

Lulusan. Manajer

Pendidikan, 9(4).

Usman, Uzer, (2008). Menjadi guru

Profesional. Bandung: Remaja

Rosdakarya 